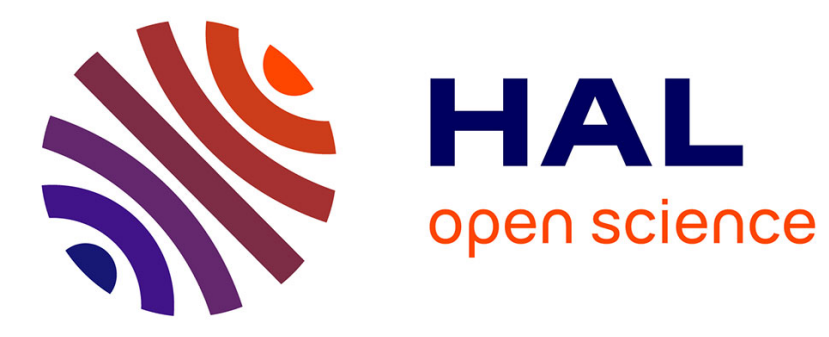

\title{
Large-scale organization of carbon dioxide discharge in the Nepal Himalayas
}

Frédéric Girault, Laurent Bollinger, Mukunda Bhattarai, Bharat Prasad

Koirala, Christian France-Lanord, Sudhir Rajaure, Jérôme Gaillardet, Monique Fort, Soma Nath Sapkota, Frédéric Perrier

\section{To cite this version:}

Frédéric Girault, Laurent Bollinger, Mukunda Bhattarai, Bharat Prasad Koirala, Christian FranceLanord, et al.. Large-scale organization of carbon dioxide discharge in the Nepal Himalayas. Geophysical Research Letters, 2014, 41 (18), p.1-9. 10.1002/2014GL060873 . hal-01201563

\section{HAL Id: hal-01201563 https://hal.science/hal-01201563}

Submitted on 18 Sep 2015

HAL is a multi-disciplinary open access archive for the deposit and dissemination of scientific research documents, whether they are published or not. The documents may come from teaching and research institutions in France or abroad, or from public or private research centers.
L'archive ouverte pluridisciplinaire HAL, est destinée au dépôt et à la diffusion de documents scientifiques de niveau recherche, publiés ou non, émanant des établissements d'enseignement et de recherche français ou étrangers, des laboratoires publics ou privés. 


\section{Geophysical Research Letters}

\section{RESEARCH LETTER}

10.1002/2014GL060873

Key Points:

- $\mathrm{CO}_{2}$ and radon fluxes were measured near 13 hot springs in the Nepal Himalayas

- Integrated $\mathrm{CO}_{2}$ discharges are heterogeneous but coherently spatially organized

- A $110 \mathrm{~km}$ long metamorphic $\mathrm{CO}_{2}$-producing segment is clearly defined

Supporting Information:

- Readme

- Figure S1

- Table S1

- Table S2

Correspondence to:

F. Girault,

girault@biotite.ens.fr

\section{Citation:}

Girault, F., L. Bollinger, M. Bhattarai, B. P. Koirala, C. France-Lanord, S. Rajaure, J. Gaillardet, M. Fort, S. N. Sapkota, and

F. Perrier (2014), Large-scale organization of carbon dioxide discharge in the Nepal Himalayas, Geophys. Res. Lett., 41, doi:10.1002/2014GL060873.

Received 12 JUN 2014 Accepted 29 AUG 2014 Accepted article online 2 SEP 2014

\section{Large-scale organization of carbon dioxide discharge in the Nepal Himalayas}

\author{
Frédéric Girault ${ }^{1,2}$, Laurent Bollinger ${ }^{3}$, Mukunda Bhattarai ${ }^{4}$, Bharat Prasad Koirala ${ }^{4}$, \\ Christian France-Lanord ${ }^{5}$, Sudhir Rajaure ${ }^{4}$, Jérôme Gaillardet ${ }^{1}$, Monique Fort ${ }^{6}$, \\ Soma Nath Sapkota ${ }^{4}$, and Frédéric Perrier ${ }^{1}$
}

${ }^{1}$ Institut de Physique du Globe de Paris, Sorbonne Paris Cité, Université Paris Diderot, CNRS UMR 7154, Paris, France, ${ }^{2}$ Now at Laboratoire de Géologie, École Normale Supérieure, CNRS UMR 8538, Paris, France, ${ }^{3}$ CEA, DAM, DIF, Arpajon, France, ${ }^{4}$ National Seismological Centre, Department of Mines and Geology, Kathmandu, Nepal, ${ }^{5}$ Centre de Recherches Pétrographiques et Géochimiques, Université de Nancy, CNRS UMR 7358, Vandoeuvre-lès-Nancy, France, ${ }^{6}$ Département de Géographie, Sorbonne Paris Cité, Université Paris Diderot, CNRS UMR Prodig 8586, Paris, France

Abstract Gaseous carbon dioxide $\left(\mathrm{CO}_{2}\right)$ and radon-222 release from the ground was investigated along the Main Central Thrust zone in the Nepal Himalayas. From $2200 \mathrm{CO}_{2}$ and 900 radon-222 flux measurements near 13 hot springs from western to central Nepal, we obtained total $\mathrm{CO}_{2}$ and radon discharges varying from $10^{-3}$ to $1.6 \mathrm{~mol} \mathrm{~s}^{-1}$ and 20 to $1600 \mathrm{~Bq} \mathrm{~s}^{-1}$, respectively. We observed a coherent organization at spatial scales of $\approx 10 \mathrm{~km}$ in a given region: low $\mathrm{CO}_{2}$ and radon discharges around Pokhara (midwestern Nepal) and in the Bhote Kosi Valley (east Nepal); low $\mathrm{CO}_{2}$ but large radon discharges in Lower Dolpo (west Nepal); and large $\mathrm{CO}_{2}$ and radon discharges in the upper Trisuli Valley (central Nepal). A $110 \mathrm{~km}$ long $\mathrm{CO}_{2}$-producing segment, with high carbon isotopic ratios, suggesting metamorphic decarbonation, is thus evidenced from $84.5^{\circ} \mathrm{E}$ to $85.5^{\circ} \mathrm{E}$. This spatial organization could be controlled by geological heterogeneity or large Himalayan earthquakes.

\section{Introduction}

Convergent zones play an essential role in the global carbon dioxide $\left(\mathrm{CO}_{2}\right)$ balance of the Earth $[$ Kerrick and Caldeira, 1998]. In addition to their role of atmospheric $\mathrm{CO}_{2}$ sink through silicate weathering [Gaillardet et al., 1999; Gaillardet and Galy, 2008; Wolff-Boenisch et al., 2009], large orogens are also the location of the production and release of $\mathrm{CO}_{2}$-rich fluids [Irwin and Barnes, 1980]. Major active fault zones appear as a complex system where fluid circulation, crustal permeability, and possibly earthquake occurrence might be interrelated dynamically [Manning and Ingebritsen, 1999; Ingebritsen and Manning, 2010; Manga et al., 2012].

The Himalayas offer a natural laboratory where this essential coupling can be studied. High seismic activity is concentrated on a midcrustal ramp located below the Main Central Thrust (MCT) zone on the Main Himalayan Thrust accommodating the $2 \mathrm{~cm} \mathrm{yr}^{-1}$ convergence between India and Southern Tibet [Avouac, 2003; Ader et al., 2012], where fluid occurrence might explain the high electrical conductivity observed by magnetotelluric sounding [Lemonnier et al., 1999]. Seasonal variations of seismicity [Bollinger et al., 2007] and deformation [Bettinelli et al., 2008; Chanard et al., 2014] can be related to surface hydrological forcing.

Evidence of $\mathrm{CO}_{2}$ release exists in the MCT zone of central Nepal. First, high alkalinity of hot springs up to $56 \times 10^{-3} \mathrm{~mol} \mathrm{~L}^{-1}$ was shown to contribute from 0.5 to $25 \%$ to the total dissolved inorganic carbon (DIC) of the entire Narayani watershed [Evans et al., 2004]. Furthermore, the high carbon isotopic ratios $\left(\delta^{13} \mathrm{C}\right)$ of the hot springs, with values reaching $+13 \%$, suggested a metamorphic decarbonation source at depth and a massive $\mathrm{CO}_{2}$ degassing near the water table, larger than $75 \%$ in the Trisuli and Marsyandi Valleys [Becker et al., 2008; Evans et al., 2008]. Second, explicit $\mathrm{CO}_{2}$ emission from the ground was discovered near hot springs of the Trisuli Valley, in the Syabru-Bensi hydrothermal system (SBHS) [Perrier et al., 2009], where it was found to be associated with a radon-222 signature and was subsequently mapped in detail [Girault et al., 2014], providing a valuable baseline for long-term monitoring [Girault et al., 2009]. In this paper, we present the results of systematic search and measurement of gaseous $\mathrm{CO}_{2}$ release in the vicinity of other significant hot springs from western to eastern Nepal. 


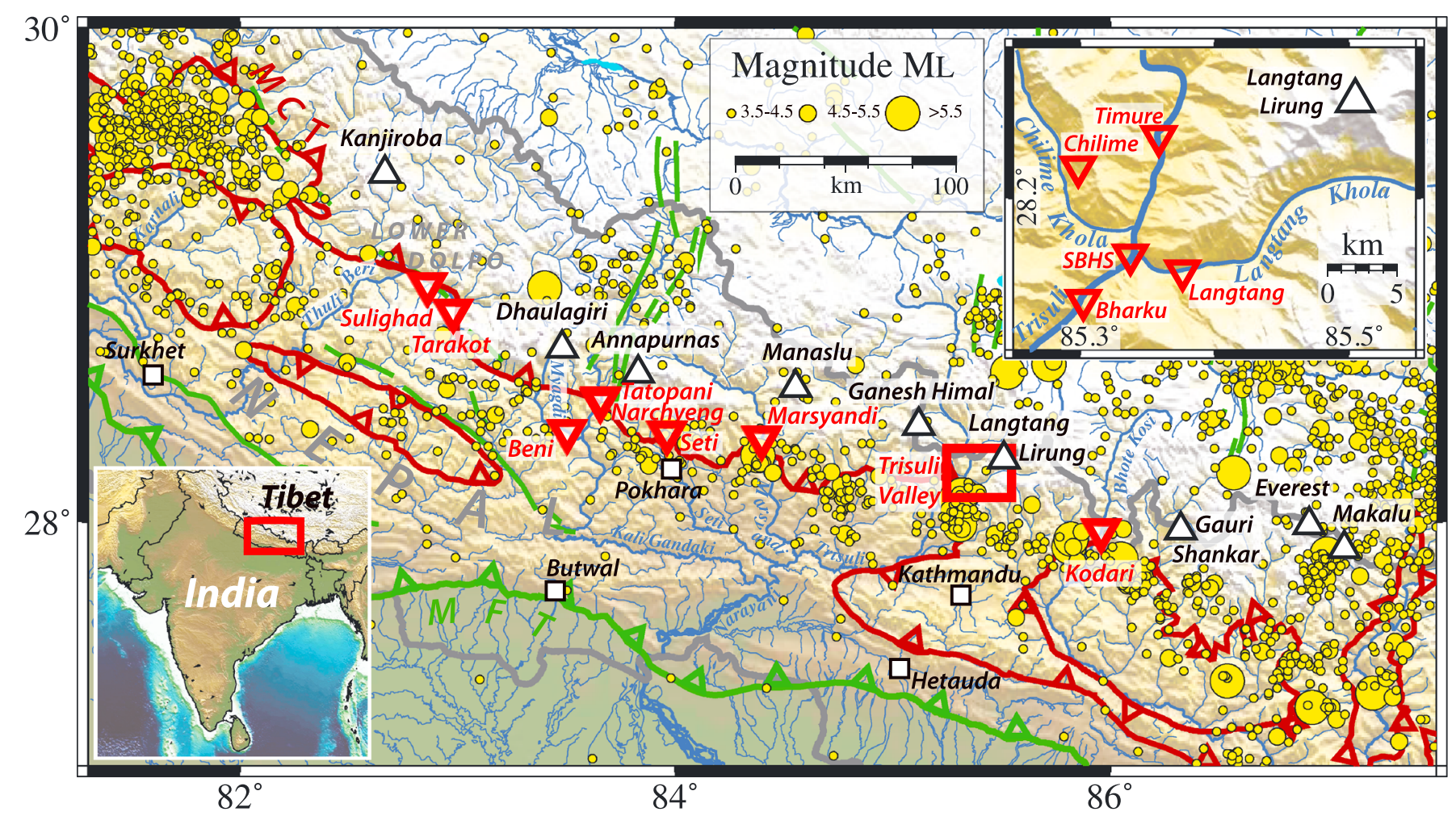

Figure 1. Overview of sites in the Nepal Himalayas. Main Central Thrust (MCT) (brown), Main Frontal Thrust (MFT) faults (green), and highest summits (white triangles) are shown. Earthquake epicenters are taken from the 1994-2012 catalog (Nepal National Seismological Centre) [Pandey et al., 1999]. The bottom left inset shows geographical location. The top right inset shows location of sites in the upper Trisuli Valley. SBHS is the Syabru-Bensi hydrothermal system in central Nepal.

\section{Description of the Sites in the MCT Zone}

The 2 to $10 \mathrm{~km}$ thick MCT shear zone in Nepal (Figure 1), associated with the steep topographic rise of the High Himalayas, places high-grade metamorphic rocks of the Greater Himalayan Sequence over low-grade metamorphic rocks of the Lesser Himalayan Sequence [Le Fort, 1975; Upreti, 1999]. This region is also characterized by numerous hot springs [Evans et al., 2004].

In this work, we measured the diffuse $\mathrm{CO}_{2}$ discharge in the vicinity of 13 of these hot springs (Table 1 and Table S1 in the supporting information). All the main hot springs along the Trisuli River in central Nepal were studied (Figure 1, inset): Timure and Chilime, Langtang, and Bharku, located north, east, and south of the SBHS, respectively. Springs located in midwestern Nepal, such as the Myagdi (Beni), Kali Gandaki (Tatopani, Narchyeng), Seti, and Marsyandi Rivers were also examined (Figure 1). This set was complemented (Figure 1) by the Kodari hot spring east of Kathmandu and two hot springs in Lower Dolpo (western Nepal) near tributaries of the Thuli Bheri River: Sulighad near Juphal airport, and Tarakot $20 \mathrm{~km}$ eastward.

These hydrothermal systems show various settings (Tables 1, S1, and S2). Kodari, Chilime, Beni, and Tatopani springs, with significant flow rate $\left(>1 \mathrm{Ls}^{-1}\right)$, are major pilgrimage and touristic sites. Sulighad, Tarakot, Timure, Bharku, and Langtang springs, with smaller flow rate $\left(<1 \mathrm{Ls}^{-1}\right)$, are largely preserved in natural conditions due to their remote location. SBHS, Timure, and Seti springs, with insufficient flow rate to attract much economic activity, show moderate human impacts limited to cemented basins. SBHS, Tatopani, and Chilime sites have pronounced $\mathrm{H}_{2} \mathrm{~S}$ odor helpful to identify $\mathrm{CO}_{2}$ degassing [Girault et al., 2009], a signature totally lacking at Sulighad and Tarakot sites despite a similar geological context. At SBHS and Timure sites, several independent $\mathrm{CO}_{2}$ discharge zones, separated by $>500 \mathrm{~m}$, were found.

\section{Measurement Methods}

At each site, a systematic experimental approach developed in the SBHS was implemented. Methods are briefly recalled here. Details are given in Girault et al. [2014]. 
Table 1. Characteristics of $\mathrm{CO}_{2}$ and Radon Emission From the Ground

\begin{tabular}{|c|c|c|c|c|c|c|c|c|c|}
\hline \multirow[b]{3}{*}{ Site } & \multirow{3}{*}{$\begin{array}{l}\text { Estimated DIC } \\
\text { Discharge From } \\
\text { Hot Springs } \\
\left(10^{-3} \mathrm{~mol} \mathrm{~s}^{-1}\right)\end{array}$} & \multicolumn{8}{|c|}{ Diffuse Gaseous $\mathrm{CO}_{2}$ Discharge } \\
\hline & & \multicolumn{2}{|c|}{$\mathrm{CO}_{2}$ Fluxes } & \multirow[b]{2}{*}{$\mathrm{N}^{\mathrm{a}}$} & \multirow{2}{*}{$\begin{array}{l}\text { Radon Fluxes } \\
\text { Min-Max Range } \\
\left(10^{-3} \mathrm{~Bq} \mathrm{~m}^{-2} \mathrm{~s}^{-1}\right)\end{array}$} & $\begin{array}{l}\text { Correlation } \mathrm{CO}_{2^{-}} \\
\text {Radon (Figure 2) }\end{array}$ & \multicolumn{2}{|c|}{$\begin{array}{l}\text { Estimated Global } \\
\text { Discharges }\end{array}$} & \multirow{2}{*}{$\begin{array}{c}\delta^{13} C_{\text {gas }} \text { From } \mathrm{CO}_{2} \\
\text { (PDB) (\%o) Mean } \\
\pm 1 \sigma(\text { Min/Max })\end{array}$} \\
\hline & & $\mathrm{N}^{\mathrm{a}}$ & $\begin{array}{c}\text { Range } \\
\left(\mathrm{g} \mathrm{m}^{-2} \mathrm{~d}^{-1}\right)\end{array}$ & & & $N^{b}$ & $\begin{array}{l}\mathrm{CO}_{2} \text { Discharge } \\
\left(10^{-3} \mathrm{~mol} \mathrm{~s}^{-1}\right)\end{array}$ & $\begin{array}{l}\text { Radon Discharge } \\
\left(\mathrm{Bq} \mathrm{s}^{-1}\right)\end{array}$ & \\
\hline \multicolumn{10}{|c|}{ Western Nepal } \\
\hline \multicolumn{10}{|l|}{ Lower Dolpo } \\
\hline Sulighad & $8.4 \pm 3.3^{9}$ & 65 & $1.1-259$ & 50 & $7.0-3070$ & 44 & $3.0 \pm 0.6$ & $180 \pm 40$ & $\begin{array}{c}-10.2 \pm 0.1 \\
(-10.2 /-10.1)\end{array}$ \\
\hline Tarakot & $1.1 \pm 0.3^{g}$ & 119 & $0.8-70$ & 45 & $0-1410$ & 35 & $3.8 \pm 0.8$ & $70 \pm 15$ & $-11.7 \pm 0.3$ \\
\hline \multicolumn{10}{|c|}{ Midwestern Nepal } \\
\hline Beni & $14.1 \pm 4.2^{f, g}$ & 49 & $0.7-35$ & 23 & $0-27$ & 23 & $<0.4$ & $<16$ & n.m. \\
\hline \multicolumn{10}{|c|}{ Kali Gandaki Valley } \\
\hline Narchyeng & $9.7 \pm 3.9^{\mathrm{g}}$ & 33 & $1.7-70$ & 18 & $7.0-111$ & 14 & $<0.4$ & $<16$ & n.m. \\
\hline Tatopani & $14.7 \pm 4.5^{f, g}$ & 81 & $0.6-163$ & 36 & $0-403$ & 36 & $<0.4$ & $<16$ & n.m. \\
\hline Seti & $32 \pm 16^{f, g}$ & 23 & $2.4-176$ & 15 & $0.3-66$ & 15 & $2.5 \pm 0.5$ & $<16$ & n.m. \\
\hline Marsyandi & $14.1 \pm 6.1^{d, e, f, g}$ & 2 & $2800-3600$ & 0 & n.m. & 0 & $>130$ & n.m. & $-2.8 \pm 0.1$ \\
\hline \multicolumn{10}{|l|}{ Central Nepal } \\
\hline Chilime & $15.7 \pm 3.3^{d, g}$ & 192 & $3.4-123,000$ & 61 & $5.0-3810$ & 59 & $390 \pm 100$ & $290 \pm 70$ & $-1.6 \pm 0.1$ \\
\hline Bharku & n.m. & 7 & $1.9-20$ & 0 & n.m. & 0 & $<0.4$ & n.m. & n.m. \\
\hline \multicolumn{10}{|l|}{$S B H S^{\mathrm{C}}$} \\
\hline GZ1-2 & $123 \pm 38^{d, f, g}$ & 427 & $2.5-236,000$ & 184 & $4.5-38,500$ & 112 & $900 \pm 100$ & $340 \pm 70$ & $\begin{array}{l}-0.88 \pm 0.09 \\
(-1.3 /-0.77)\end{array}$ \\
\hline GZ3 & $21.1 \pm 9.3^{9}$ & 580 & $2.0-19,000$ & 203 & $1.2-10,400$ & 82 & $740 \pm 130$ & $1040 \pm 210$ & $-0.5 \pm 0.1$ \\
\hline Total & $150 \pm 50^{\mathrm{d}, \mathrm{f}, \mathrm{g}}$ & 1314 & $2.0-236,000$ & 529 & $1.2-38,500$ & 240 & $1600 \pm 400$ & $1600 \pm 300$ & $\begin{array}{c}-0.85 \pm 0.09 \\
(-1.3 /-0.5)\end{array}$ \\
\hline Timure & $12.9 \pm 2.6^{\mathrm{d}, \mathrm{f}, \mathrm{g}}$ & 294 & $0.7-11,100$ & 123 & $0-1640$ & 114 & $830 \pm 170$ & $840 \pm 170$ & $\begin{array}{l}-1.1 \pm 0.4 \\
(-1.6 /-0.6)\end{array}$ \\
\hline Langtang & $0.45 \pm 0.14^{f, g}$ & 5 & $3.5-6.5$ & 0 & n.m. & 0 & $<0.4$ & n.m. & n.m. \\
\hline Kodari & $25 \pm 10^{f, g}$ & 5 & $0-31$ & 0 & n.m. & 0 & $<0.4$ & n.m. & n.m. \\
\hline Total & $>300 \pm 100$ & 2189 & $0-236,000$ & 900 & $0-38,500$ & 580 & $>3000 \pm 700$ & $>3000 \pm 600$ & $(-11.7 /-0.5)$ \\
\hline
\end{tabular}

${ }^{\mathrm{a}}$ Number of $\mathrm{CO}_{2}$ and radon flux measurements.

${ }^{b}$ Number of measurement points for $\mathrm{CO}_{2}$-radon correlation (see Figure 2).

'Data from the SBHS are detailed in Girault et al. [2014].

Data from Becker [2005].

Data from Becker et al. [2008].

'Data from Evans et al. [2008].

${ }^{9}$ Data from this study.

n.m.: not measured.

$\mathrm{CO}_{2}$ and radon fluxes, expressed in $\mathrm{g} \mathrm{m}^{-2} \mathrm{~d}^{-1}$ and $\mathrm{Bq} \mathrm{m}^{-2} \mathrm{~s}^{-1}$, respectively, were measured with the accumulation chamber method. After the chamber is installed on the ground, gas concentration was monitored as a function of time, and the initial rate of increase provides a measurement of the flux. The method was tested in detail in the field, and experimental uncertainties were determined to be $5-40 \%$ for $\mathrm{CO}_{2}$ flux and $8-35 \%$ for radon flux. An overall common uncertainty of $5 \%$ was added quadratically. Mean $\mathrm{CO}_{2}$ and radon fluxes in background locations without degassing were $16.6 \pm 1.3 \mathrm{~g} \mathrm{~m}^{-2} \mathrm{~d}^{-1}$ and $0.10 \pm 0.02 \mathrm{~Bq} \mathrm{~m}^{-2} \mathrm{~s}^{-1}$, respectively. To obtain the total discharge, expressed in $\mathrm{mol} \mathrm{s}^{-1}$ or $\mathrm{t}^{-1}$ for $\mathrm{CO}_{2}$ and $\mathrm{Bq} \mathrm{s}^{-1}$ or $\mathrm{MBq} \mathrm{d}^{-1}$ for radon, spatial integration was performed using kriging and interpolation of the available flux data, with uncertainty varying from 10 to $60 \%$ as estimated by Monte Carlo simulations.

Sampling of gas and spring water was performed using glass tubes and copper tubes, respectively. Determination of the $\mathrm{CO}_{2}$ fraction was done manometrically. Carbon isotopic ratios of $\mathrm{CO}_{2}\left(\delta^{13} \mathrm{C}\right.$, defined relative to the standard values of Pee Dee belemnite, PDB) were obtained by mass spectrometry. 


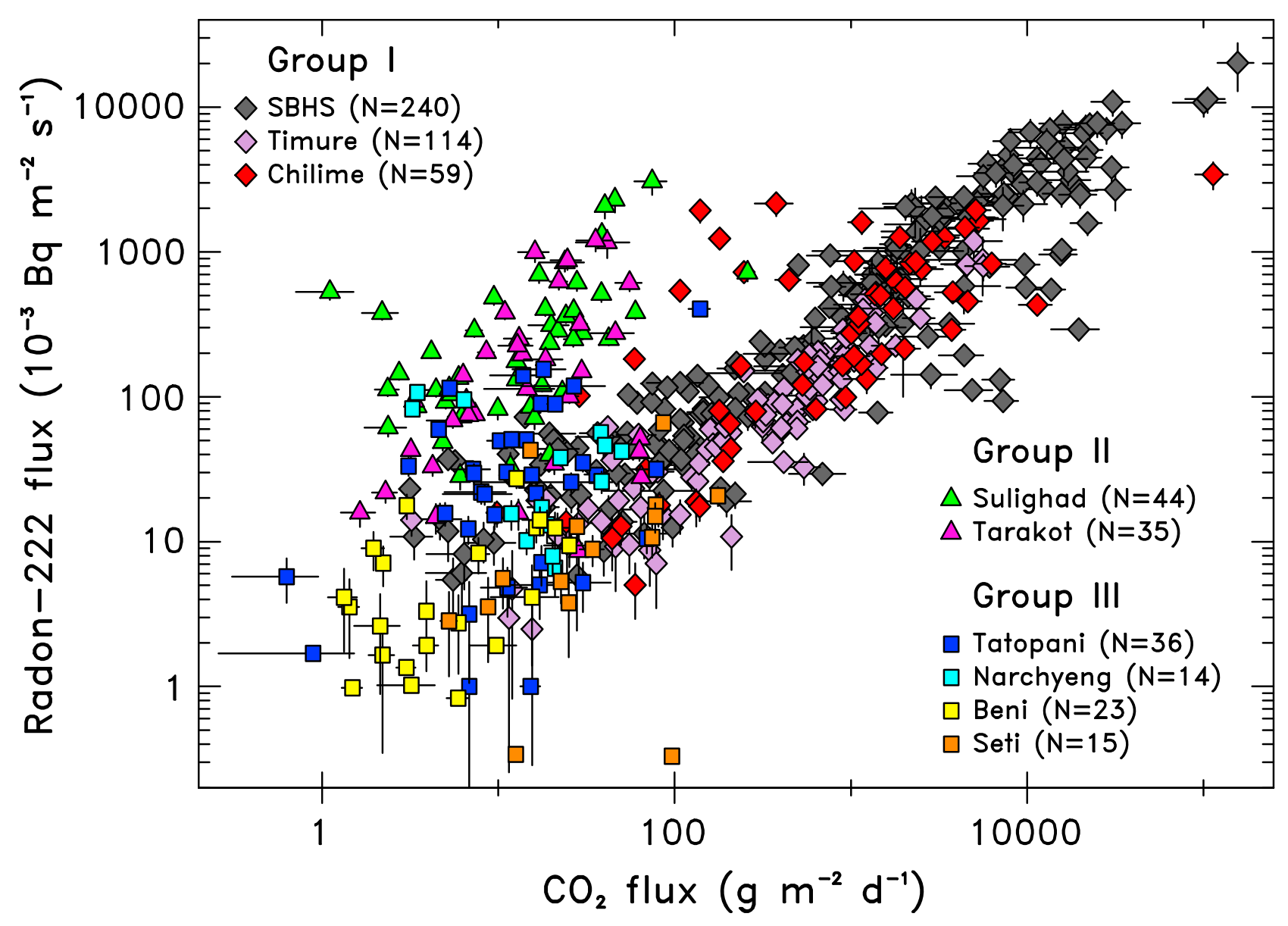

Figure 2. $\mathrm{CO}_{2}$ flux versus radon-222 flux.

Radon concentration, expressed in $\mathrm{Bq} \mathrm{L}^{-1}$, was systematically measured on site in hot and cold water springs by radon emanometry in air [Girault and Perrier, 2014]. Experimental uncertainties were 5-30\%. Radium concentration in water, expressed in $\mathrm{Bq} \mathrm{L}^{-1}$, was determined in a similar manner in the laboratory.

Methods could not always be applied optimally, owing to several factors (electricity, permission, human impact, and lack of time). Searches were initiated in the immediate vicinity of the hot springs, assisted by infrared thermal imaging. Local people could sometimes indicate suspected gas discharge zones where lethal accidents had occurred.

\section{Results}

Measurements were carried out during the dry winter seasons between December 2007 and January 2011. Uncertainties correspond to one sigma standard deviation (68\% confidence interval), and averages are geometric means.

\section{1. $\mathrm{CO}_{2}$ Flux and Integrated Discharge}

A total of $2189 \mathrm{CO}_{2}$ and 900 radon fluxes were measured at 580 measurement points (Table 1 and Figure 2). Maximum $\mathrm{CO}_{2}$ fluxes of $236 \pm 50 \mathrm{~kg} \mathrm{~m}^{-2} \mathrm{~d}^{-1}$ and $123 \pm 25 \mathrm{~kg} \mathrm{~m}^{-2} \mathrm{~d}^{-1}$ were recorded in the SBHS and at Chilime, respectively. Significant $\mathrm{CO}_{2}$ discharges of $1.6 \pm 0.4,0.83 \pm 0.17$, and $0.39 \pm 0.10 \mathrm{~mol} \mathrm{~s}^{-1}$ were observed at the SBHS, Timure, and Chilime sites, respectively. At Timure, significant discharge was observed despite smaller $\mathrm{CO}_{2}$ fluxes (maximum of $11.1 \pm 2.8 \mathrm{~kg} \mathrm{~m}^{-2} \mathrm{~d}^{-1}$ ), due to a larger surface area of $\mathrm{CO}_{2}$ degassing, extending $150 \mathrm{~m}$ from the hot spring on an infrared image (Table S1). Significant $\mathrm{CO}_{2}$ discharge is thus not a specific feature of the SBHS but is a widespread feature of the upper Trisuli Valley in central Nepal. 


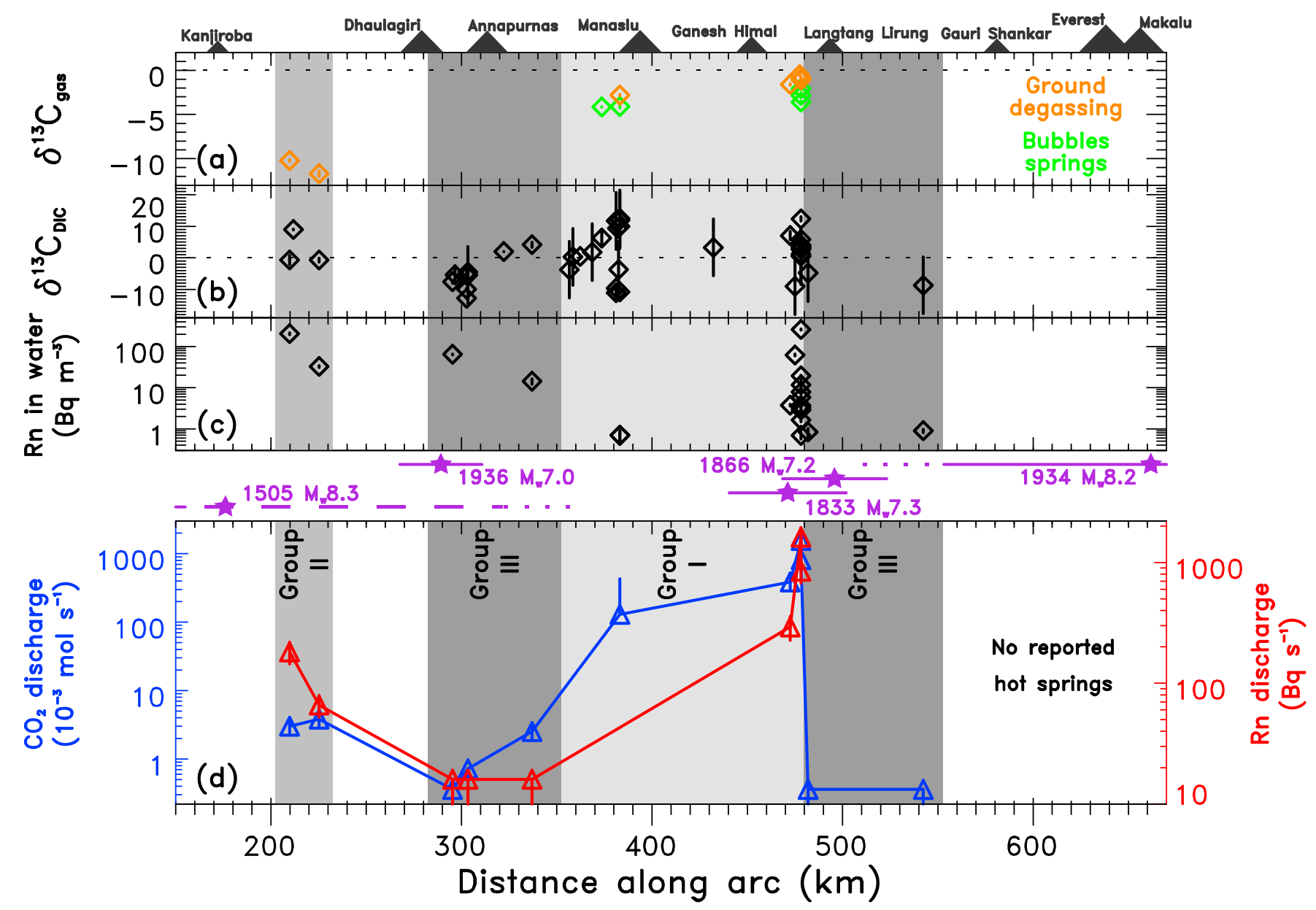

Figure 3. Characteristics of $\mathrm{CO}_{2}$ degassing from the ground and from water along the Nepal Himalayan arc: (a) Carbon isotope ratios of gaseous $\mathrm{CO}_{2}$ from the ground and bubbles in springs, (b) carbon isotope ratios of water (dissolved inorganic carbon), (c) radon concentration in spring waters, and (d) $\mathrm{CO}_{2}$ and radon discharge from the ground (see supporting information). Data are summarized in Tables 1, S1, and S2. Epicenter and rupture lengths of the last significant earthquakes are displayed: the megaquakes of $1505(M \geq 8)$ [Ambraseys and Jackson, 2003] and $1934\left(M_{w} 8.2\right)$ [Ambraseys and Douglas, 2004; Sapkota et al., 2013], and the intermediate earthquakes of $1833\left(M_{w} 7.3\right), 1866\left(M_{w} 7.2\right)$, and $1936\left(M_{w} 7.0\right)$ [Gutenberg and Richter, 1949; Szeliga et al., 2010].

By contrast, modest $\mathrm{CO}_{2}$ discharge, similar to background values, was identified southward at Bharku and eastward at Langtang and Kodari. Similarly, in midwestern Nepal, modest $\mathrm{CO}_{2}$ discharge was observed at Tatopani. Modest $\mathrm{CO}_{2}$ fluxes were also measured at all sites investigated from Beni to Seti hot springs. In Marsyandi Valley, only two points were measured, but they gave significant flux values (mean of $3200 \pm 300 \mathrm{~g} \mathrm{~m}^{-2} \mathrm{~d}^{-1}$ ). In western Nepal at Sulighad and Tarakot, maximum $\mathrm{CO}_{2}$ fluxes from the ground $\left(259 \pm 22\right.$ and $\left.70 \pm 5 \mathrm{~g} \mathrm{~m}^{-2} \mathrm{~d}^{-1}\right)$ were significantly above local background flux of $6.5 \pm 0.5 \mathrm{~g} \mathrm{~m}^{-2} \mathrm{~d}^{-1}$, but $\mathrm{CO}_{2}$ discharges are small.

To summarize, substantial $\mathrm{CO}_{2}$ discharge has thus far only been detected between the Marsyandi and upper Trisuli Valleys, i.e., along a $110 \mathrm{~km}$ long region of the Nepal Himalayan belt. Westward and eastward of this region, only low $\mathrm{CO}_{2}$ discharge, close to background level, was identified (Figure 3).

\subsection{Radon Signature of the $\mathrm{CO}_{2}$ Discharge}

Significant radon flux was observed in association with the $\mathrm{CO}_{2}$ at all sites (Figure 2 and Table 1). Radon fluxes $>1 \mathrm{~Bq} \mathrm{~m}^{-2} \mathrm{~s}^{-1}$, similar to fluxes in the SBHS [Girault et al., 2014], were observed at Timure and Chilime, yielding radon discharges of $840 \pm 170$ and $290 \pm 70 \mathrm{~Bq} \mathrm{~s}^{-1}$, respectively, significant compared with the discharge in the SBHS $\left(1600 \pm 300 \mathrm{~Bq} \mathrm{~s}^{-1}\right)$. In Dolpo, radon discharges were also significant $\left(180 \pm 40\right.$ and $\left.70 \pm 15 \mathrm{~Bq} \mathrm{~s}^{-1}\right)$. Insignificant radon discharge, consistent with the regional background, characterized all other sites. 


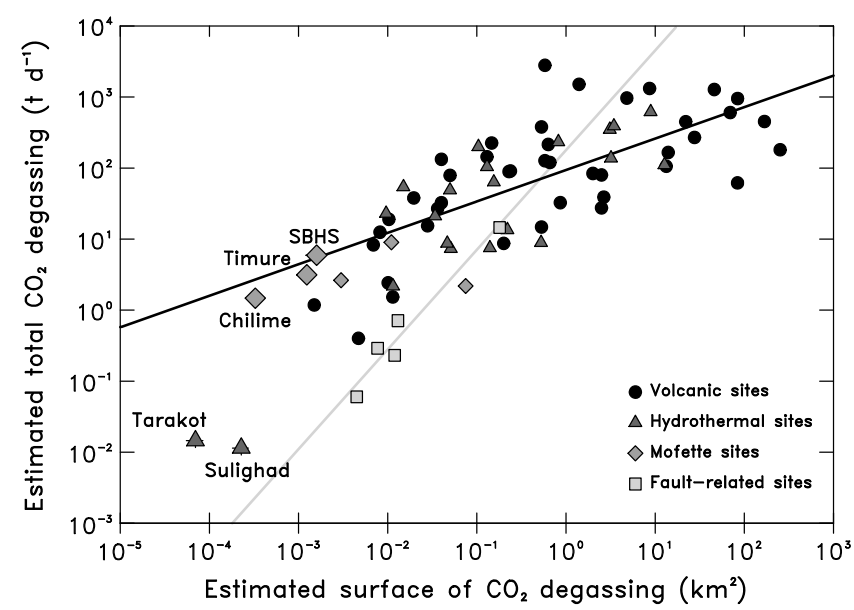

Figure 4. Surface area versus estimated total $\mathrm{CO}_{2}$ degassing from the ground for our sites together with other selected sites (see review in Girault et al. [2014]). Solid lines are power law best fits: black line for volcanic sites and gray line for fault-related sites.
The relationship between radon flux and $\mathrm{CO}_{2}$ flux varied from site to site (Figures 2 and 3). For example, the case of Dolpo (Sulighad and Tarakot) is conspicuously different, with maximum radon flux reaching $3.1 \pm 0.6$ and $1.4 \pm 0.2 \mathrm{~Bq} \mathrm{~m}^{-2} \mathrm{~s}^{-1}$, similar to fluxes measured in central Nepal, while the $\mathrm{CO}_{2}$ flux is relatively low. We therefore propose a classification of the sites based on $\mathrm{CO}_{2}$ and radon flux data: a first group (group I) with large $\mathrm{CO}_{2}$ and radon discharges (upper Trisuli Valley including SBHS, Timure, and Chilime, possibly Marsyandi); a second group (group II) with low $\mathrm{CO}_{2}$ discharge but large radon discharge (Sulighad and Tarakot in Lower Dolpo); and a third group (group III) with low $\mathrm{CO}_{2}$ and radon discharges (Langtang and Bharku in central Nepal, Kodari to the east, Tatopani, Narchyeng, Beni, and Seti in midwestern Nepal). We did not observe a case of large $\mathrm{CO}_{2}$ discharge with low radon discharge.

Values of radon concentration in the hot springs confirm this organization (Figure 3 and Table S2): large in Dolpo $\left(205 \pm 10\right.$ and $\left.33 \pm 2 \mathrm{~Bq} \mathrm{~L}^{-1}\right)$, but small in the hot springs of midwestern and central Nepal $\left(0.70 \pm 0.18 \mathrm{~Bq} \mathrm{~L}^{-1}\right.$ at Marsyandi, $3.8 \pm 0.2 \mathrm{~Bq} \mathrm{~L}^{-1}$ at Chilime, from $0.7 \pm 0.1$ to $19 \pm 1 \mathrm{~Bq} \mathrm{~L}^{-1}$ in the SBHS, from $5.8 \pm 0.4$ to $12 \pm 4 \mathrm{~Bq} \mathrm{~L}^{-1}$ at Timure, and $0.90 \pm 0.09 \mathrm{~Bq} \mathrm{~L}^{-1}$ at Kodari). Except at Langtang and Kodari, radon concentration in water was high when $\mathrm{CO}_{2}$ discharge was insignificant and low in the presence of large $\mathrm{CO}_{2}$ discharge.

\subsection{Carbon Isotopic Anomalies}

In central Nepal, gaseous $\mathrm{CO}_{2}$ samples showed $\delta^{13} \mathrm{C}$ between $-1.6 \pm 0.1$ and $-0.5 \pm 0.1 \%$ (mean of $-1.2 \pm 0.2 \%$ ), consistent with previous data which support the concept of a deep metamorphic decarbonation source [Becker et al., 2008; Evans et al., 2008; Perrier et al., 2009]. In Dolpo, similar $\delta^{13} \mathrm{C}$ are obtained at both sites, $-10.2 \pm 0.1$ and $-11.7 \pm 0.3 \%$, intermediate values between the mean $\delta^{13} \mathrm{C}$ of central Nepal and that of biogenic carbon ( $-25 \pm 5 \%$ ) [Cerling, 1984].

A synthesis of available values of $\delta^{13} C_{D I C}$ for the dissolved inorganic carbon in hot springs is given in Figure 3 and Table S2. Compared with the $\delta^{13} \mathrm{C}$ of gas, there was a larger dispersion of $\delta^{13} C_{D I C}$ in water along the Nepal Himalayan belt, ranging from -13.8 to $+13.2 \%$. The largest average values were observed in the Marsyandi (12.5\%o) [Becker et al., 2008] and upper Trisuli Valleys (12.3 $\pm 0.7 \%$ ) [Becker, 2005; Evans et al., 2008].

\section{Discussion}

We divide the studied sites into three groups, on the basis of $\mathrm{CO}_{2}$ and radon data (Figures 3 and S1). These must reflect source and transport processes, and a preliminary interpretation is proposed below. In the hydrothermal model of Becker et al. [2008] and Evans et al. [2008], metamorphic reactions at 10-20 km depth produce $\mathrm{CO}_{2}$ which percolates through fracture networks, reaching the MCT fault system, where it mixes with meteoric water which eventually is discharged at $60-80^{\circ} \mathrm{C}$ at the surface. At or near the water table, $\mathrm{CO}_{2}$ may interact with the atmosphere and degas, enhancing the remnant $\delta^{13} \mathrm{C}_{\mathrm{DIC}}$. The simplest model for the radon signature is degassing of the radon contained in water [Girault and Perrier, 2014]. This model predicts a relationship between radon and $\mathrm{CO}_{2}$ discharge (Figure S1). For some sites (group II), the radon signature can be accounted for by a small amount of degassing of radon-rich hydrothermal water. By contrast, even when a broad range of conditions are considered (gray band), this model cannot account for the largest $\mathrm{CO}_{2}$ and radon discharges observed at group I sites Timure and SBHS. The Chilime site appears here intermediate, marginally compatible with simple degassing of radon-bearing water. This analysis indicates that group I is 
anomalous and signals the presence of another mechanism, with radon being incorporated at a depth after $\mathrm{CO}_{2}$ is degassed from water or perhaps suggesting that $\mathrm{CO}_{2}$ is transported and released independently from hydrothermal circulations [Girault and Perrier, 2014]. Differences in the radon flux can be accounted for by different depths of $\mathrm{CO}_{2}$ degassing or by variations in the effective radium concentration of rocks (i.e., the radon source term) [Girault et al., 2012; Girault and Perrier, 2014, Figure 14].

In a given region, sites separated by $5-10 \mathrm{~km}$ showed remarkably similar characteristics, suggesting that local topography and hydrology are not major factors controlling the $\mathrm{CO}_{2}$ heterogeneity. Instead, this consistency indicates a $\mathrm{CO}_{2}$ source depth of the same typical spatial scale (5 to $10 \mathrm{~km}$ ). The similar $\delta^{13} \mathrm{C}$ of $-1.6 \pm 0.4 \%$ points indeed the same $\mathrm{CO}_{2}$ source, most likely metamorphic decarbonation, over the Nepal Himalayan belt. However, $\mathrm{CO}_{2}$ emission is modulated along the arc. Indeed, a $110 \mathrm{~km}$ long region (Figure 3), which here coincides with group $\mathrm{I}$, showed large $\mathrm{CO}_{2}$ and radon discharges where hot springs yielded $\delta^{13} C_{\mathrm{DIC}}>10 \%$ o. Outside this region, $\mathrm{CO}_{2}$ discharge was low, and hot springs gave $\delta^{13} \mathrm{C}_{\mathrm{DIC}}<-4 \%$. Numerous factors might control this large-scale heterogeneity. First, the $\mathrm{CO}_{2}$ production rate must strongly depend on the available rock material (e.g., the thickness of Greater Himalayan Sequence units), lateral lithology (e.g., along strike changes in lithology, or the lithology of Lesser Himalayan Sequence units), temperature distribution, and other rheological factors associated with MCT activity. Second, the midcrust permeability must affect the $\mathrm{CO}_{2}$ discharge. A more detailed petrological modeling of the metamorphic reactions [Groppo et al., 2013] is however necessary before the role of permeability can be assessed. Alternative mechanisms for $\mathrm{CO}_{2}$ production involving sulfuric acid [Torres et al., 2014] may also need to be considered in this case.

The spatial organization of the $\mathrm{CO}_{2}$ emissions may be discussed also in relation with the distribution of earthquakes. Group II is located in the section of the MCT which shows the least seismic activity over the 1994-2012 time period. This is also (Figure 3) the region covered by the rupture of the large earthquake $(M \geq 8)$ of 1505 . The eastern group III section is approximately bordered to the east by the $220 \mathrm{~km}$ long rupture of the $1934 M_{w} 8.2$ Bihar Nepal earthquake [Sapkota et al., 2013; Bollinger et al., 2014], a region where no hot springs are reported. Group I, by contrast, is located in the seismic gap (Figure 3 ) between the two 1505 and 1934 earthquakes, with smaller major earthquakes $\left(7 \leq M_{w} \leq 8\right)$ which have only partially released the accumulated slip deficit since 1505 . These relations are unlikely to be coincidental, as Himalayan megaquakes must have a dramatic effect on the large-scale crustal permeability, but the current data are not sufficient to substantiate hypotheses at this stage.

The systems presented in this study are among the first examples of degassing in an active orogen away from volcanic activity. To first order, we can characterize the $\mathrm{CO}_{2}$ emission by the value of the discharge and the area of the emission, defined as the area with flux larger than $500 \mathrm{~g} \mathrm{~m}^{-2} \mathrm{~d}^{-1}$. In Figure 4, we compare these two parameters for our sites with more familiar instances of mofette sites and a selection of volcanic and hydrothermal sites (reviewed in Girault et al. [2014]). The points of group I (SBHS, Timure, and Chilime) with significant discharge over a comparatively small surface area fall at the lower edge of the trend of volcanic and hydrothermal sites. Points of this group therefore are not fundamentally different from volcanic sites, and we can name them "tectonic fumaroles." The contribution of such features, over all active orogens and convergent margins, might not be insignificant compared with active volcanoes. Group II (Sulighad and Tarakot) by contrast, are outside this trend but could be considered as extending the trend of points from major faults.

\section{Conclusions}

Diffuse $\mathrm{CO}_{2}$ emissions in the Nepal Himalayas have a remarkably uniform isotopic signature. The accompanying radon signature varies from site to site but shows coherent spatial organization. Over the $350 \mathrm{~km}$ long Nepal Himalayan arc that we investigated, significant $\mathrm{CO}_{2}$ and radon discharges appear concentrated in a $110 \mathrm{~km}$ long region spanning about $84.5^{\circ} \mathrm{E}$ to $85.5^{\circ} \mathrm{E}$. We measured a total diffuse $\mathrm{CO}_{2}$ discharge thus far of $3.0 \pm 0.7 \mathrm{~mol} \mathrm{~s}^{-1}$ (or $11 \pm 3 \mathrm{t} \mathrm{d}^{-1}$ ). This minimum estimate, dominated by three sites located in the upper Trisuli Valley in central Nepal, is larger than the contribution from dissolved inorganic carbon in hot springs $\left(<0.5 \mathrm{~mol} \mathrm{~s}^{-1}\right)$. This direct observation confirms previous inference [Becker et al., 2008; Evans et al., 2008] that gaseous release of $\mathrm{CO}_{2}$ dominates the total contribution of the Himalayas, and 
this may also be the case in other active orogens. The observed heterogeneity, however, makes extrapolation to a whole chain from a few sites particularly difficult.

This study can only be considered a first step toward obtaining a reliable estimate of $\mathrm{CO}_{2}$ release by the Himalayas. Degassing has not yet been studied in large areas of the Nepal Himalayas, including the far western region characterized by an intense seismic activity (Figure 1) and the eastern region East from Makalu. No $\mathrm{CO}_{2}$ emissions have been measured so far in India, Bhutan, or Pakistan. In western Nepal, the region from Marsyandi Valley to Ganesh Himal deserves more detailed mapping. Furthermore, we have sometimes observed degassing away from the hot springs along the MCT, at Timure or in the SBHS, for example, and our ability to measure large $\mathrm{CO}_{2}$ fluxes was due to the use of infrared images or an element of luck.

The origin of the $\mathrm{CO}_{2}$ released in the Nepal Himalayas, while likely metamorphic, remains insufficiently constrained. A better understanding of the source, including petrological [Groppo et al., 2013] and thermomechanical modeling [Bollinger et al., 2006], is mandatory before transport properties of the MCT zone can be assessed. The spatial distribution of our data suggests that in the future some attention should definitely be given to relationships between $\mathrm{CO}_{2}$ emissions, deformation, and Himalayan earthquakes. The presence of different types of diffuse $\mathrm{CO}_{2}$ emissions makes the Himalayas a unique natural laboratory where, for example, a dynamic connection between crust permeability and the earthquake cycle [Ingebritsen et al., 2006] can be studied. Such working hypotheses may have important consequences in terms of coseismic or preseismic gas bursts.

\section{Acknowledgments}

The authors thank the Department of Mines and Geology, Kathmandu, for a fruitful and enthusiastic collaboration. This research was supported in part by CNRS-INSU. This paper has been improved, thanks to the insightful comments of the Editor, Steve Ingebritsen, and one anonymous reviewer. This is IPGP contribution 3566

The Editor thanks two anonymous reviewers for their assistance in evaluating this paper.

\section{References}

Ader, T., et al. (2012), Convergence rate across the Nepal Himalaya and interseismic coupling on the Main Himalayan Thrust: Implications for seismic hazard, J. Geophys. Res., 117, B04403, doi:10.1029/2011JB009071.

Ambraseys, N. N., and D. Jackson (2003), A note on early earthquakes in northern India and southern Tibet, Curr. Sci. India, 84, $570-582$.

Ambraseys, N. N., and J. Douglas (2004), Magnitude calibration of north Indian earthquakes, Geophys. J. Int., 159(1), 165-206.

Avouac, J.-P. (2003), Mountain building, erosion, and the seismic cycle in the Nepal Himalaya, Adv. Geophys., 46, 1-80.

Becker, J. A. (2005), Quantification of Himalayan metamorphic $\mathrm{CO}_{2}$ fluxes: Impact on global carbon budgets, PhD thesis, Univ. of Cambridge, Cambridge, U. K.

Becker, J. A., M. J. Bickle, A. Galy, and T. J. B. Holland (2008), Himalayan metamorphic $\mathrm{CO}_{2}$ fluxes: Quantitative constraints from hydrothermal springs, Earth Planet. Sci. Lett., 265, 616-629.

Bettinelli, P., J.-P. Avouac, M. Flouzat, L. Bollinger, G. Ramillien, S. Rajaure, and S. Sapkota (2008), Seasonal variations of seismicity and geodetic strain in the Himalaya induced by surface hydrology, Earth Planet. Sci. Lett., 266, 332-344.

Bollinger, L., P. Henry, and J.-P. Avouac (2006), Mountain building in the Nepal Himalaya: Thermal and kinematic model, Earth Planet. Sci. Lett., $244,58-71$.

Bollinger, L., F. Perrier, J.-P. Avouac, S. Sapkota, U. Gautam, and D. R. Tiwari (2007), Seasonal modulation of seismicity in the Himalaya of Nepal, Geophys. Res. Lett., 34, L08304, doi:10.1029/2006GL029192.

Bollinger, L., S. N. Sapkota, P. Tapponnier, Y. Klinger, M. Rizza, J. Van der Woerd, D. R. Tiwari, and R. Pandey (2014), Estimating the return times of great Himalayan earthquakes in Eastern Nepal: Evidence from the Patu and Bardibas strands of the Main Frontal Thrust, J. Geophys. Res. Solid Earth, doi:10.1002/2014JB010970.

Cerling, T. E. (1984), The stable isotope composition of modern soil carbonate and its relationship to climate, Earth Planet. Sci. Lett., 71, 229-240.

Chanard, K., J.-P. Avouac, G. Ramilien, and J. Genrich (2014), Modeling deformation induced by seasonal variations of continental water in the Himalaya region: Sensitivity to Earth elastic structure, J. Geophys. Res. Solid Earth, 119, 5097-5113, doi:10.1002/2013JB010451.

Evans, M. J., L. A. Derry, and C. France-Lanord (2004), Geothermal fluxes of alkalinity in the Narayani river system of central Nepal, Geochem. Geophys. Geosyst., 5, Q08011, doi:10.1029/2004GC000719.

Evans, M. J., L. A. Derry, and C. France-Lanord (2008), Degassing of metamorphic carbon dioxide from the Nepal Himalaya, Geochem. Geophys. Geosyst., 9, Q04021, doi:10.1029/2007GC001796.

Gaillardet, J., and A. Galy (2008), Himalaya-Carbon sink or source?, Science, 320, 1727-1728.

Gaillardet, J., B. Dupré, P. Louvat, and C. J. Allègre (1999), Global silicate weathering and $\mathrm{CO}_{2}$ consumption rates deduced from the chemistry of large rivers, Chem. Geol., 159, 3-30.

Girault, F., and F. Perrier (2014), The Syabru-Bensi hydrothermal system in central Nepal: 2. Modeling and significance of the radon signature, J. Geophys. Res. Solid Earth, 119, 4056-4089, doi:10.1002/2013JB010302.

Girault, F., B. P. Koirala, F. Perrier, P. Richon, and S. Rajaure (2009), Persistence of radon-222 flux during monsoon at a geothermal zone in Nepal, J. Environ. Radioact., 100, 955-964.

Girault, F., F. Perrier, A. P. Gajurel, M. Bhattarai, B. P. Koirala, L. Bollinger, M. Fort, and C. France-Lanord (2012), Effective radium concentration across the Main Central Thrust in the Nepal Himalayas, Geochim. Cosmochim. Acta, 98, 203-227.

Girault, F., et al. (2014), The Syabru-Bensi hydrothermal system in central Nepal: 1. Characterization of carbon dioxide and radon fluxes, J. Geophys. Res. Solid Earth, 119, 4017-4055, doi:10.1002/2013JB010301.

Groppo, C., F. Rolfo, D. Castelli, and J. A. D. Connolly (2013), Metamorphic $\mathrm{CO}_{2}$ production from calc-silicate rocks via garnet-forming reactions in the CFAS- $\mathrm{H}_{2} \mathrm{O}-\mathrm{CO}_{2}$ system, Contrib. Mineral. Petrol., 166, 1655-1675.

Gutenberg, B., and C. F. Richter (1949), Seismicity of the Earth and Associated Phenomena, 295 pp., Princeton Univ. Press, Princeton, N. J. Ingebritsen, S. E., and C. E. Manning (2010), Permeability of the continental crust: Dynamic variations inferred from seismicity and metamorphism, Geofluids, 10, 193-205. 
Ingebritsen, S. E., W. E. Sanford, and C. E. Neuzil (2006), Groundwater in Geologic Processes, 2nd ed., 536 pp., Cambridge Univ. Press, Cambridge, U. K. Irwin, W. P., and I. Barnes (1980), Tectonic relations of carbon dioxide discharges and earthquakes, J. Geophys. Res., 85(B6), 3115-3121, doi:10.1029/JB085iB06p03115.

Kerrick, D. M., and K. Caldeira (1998), Metamorphic $\mathrm{CO}_{2}$ degassing from orogenic belts, Chem. Geol., 145, 213-232.

Le Fort, P. (1975), Himalayas: Collided range, present knowledge of continental arc, Am. J. Sci., A275, 1-44.

Lemonnier, C., G. Marquis, F. Perrier, J.-P. Avouac, G. Chitrakar, B. Kafle, S. Sapkota, U. Gautam, D. Tiwari, and M. Bano (1999), Electrical structure of the Himalaya of Central Nepal: High conductivity around the mid-crustal ramp along the MHT, Geophys. Res. Lett., 26(21), 3261-3264, doi:10.1029/1999GL008363.

Manga, M., I. Beresnev, E. E. Brodsky, J. E. Elkhoury, D. Elsworth, S. E. Ingebritsen, D. C. Mays, and C.-Y. Wang (2012), Changes in permeability caused by transient stresses: Field observations, experiments, and mechanisms, Rev. Geophys., 50, RG2004, doi:10.1029/2011RG000382.

Manning, C. E., and S. E. Ingebritsen (1999), Permeability of the continental crust: Implications of geothermal data and metamorphic systems, Rev. Geophys., 37(1), 127-150, doi:10.1029/1998RG900002.

Pandey, M. R., R. P. Tandukar, J.P. Avouac, J. Vergne, and T. Héritier (1999), Seismotectonics of the Nepal Himalaya from a local seismic network, J. Asian Earth Sci., 17, 703-712.

Perrier, F., et al. (2009), A direct evidence for high carbon dioxide and radon-222 discharge in Central Nepal, Earth Planet. Sci. Lett., 278, 198-207.

Sapkota, S. N., L. Bollinger, Y. Klinger, P. Tapponnier, Y. Gaudemer, and D. Tiwari (2013), Primary surface ruptures of the great Himalayan earthquakes in 1934 and 1255, Nat. Geosci., 6, 71-76.

Szeliga, W., S. Hough, S. Martin, and R. Bilham (2010), Intensity, magnitude, location, and attenuation in India for felt earthquakes since 1762, B. Seismol. Soc. Am., 100(2), 570-584.

Torres, M. A., A. J. West, and G. Li (2014), Sulphide oxidation and carbonate dissolution as a source of $\mathrm{CO}_{2}$ over geological timescales, Nature, $507,346-349$

Upreti, B. N. (1999), An overview of the stratigraphy and tectonics of the Nepal Himalaya, J. Asian Earth Sci., 17, 577-606.

Wolff-Boenisch, D., E. J. Gabet, D. W. Burbank, H. Langner, and J. Putkonen (2009), Spatial variations in chemical weathering and $\mathrm{CO}_{2}$ consumption in Nepalese High Himalayan catchments during the monsoon season, Geochim. Cosmochim. Acta, 73, 3148-3170. 